\title{
EFFECT OF CHLOROTIC STREAK ON THE YIELD OF SUGARCANE
}

\author{
P. Landrau, Jr. and J. Adsuar ${ }^{1}$ \\ INTRODUCTION
}

Chlorotic streak, a virus disease of sugarcane, is of considerable potential economic importance since it has been observed to cause a marked reduction in yields of cane and in the germination and tillering of plant cane.

During the 1932 Conference of the International Society of Sugarcane Technologists, Willbrink, Bell and Martin reported having observed the disease in Puerto Rico, and each recognized it as being identical with a disease occurring in Java, Australia, and Hawaii. In 1946, Adsuar (2) ${ }^{2}$ definitely demonstrated its presence in Puerto Rico on the sugarcane variety P.O.J. 2878.

In 1942 Abbott and Ingram (3) proved that Draeculacephala portola transmitted chlorotic streak in Louisiana. 1). portola has not been reported in Puerto Rico where chlorotic streak apparently spreads under natural conditions, although other members of the genus Draeculacephala are present.

\section{DIAGNOSIS AND PREVALENCE OF STREAK}

The most reliable diagnostic symptom of the disease is the appearance on the leaves of chlorotic streaks (fig. 1) which vary in length from a few millimeters to nearly the entire length of the leaf. The streaks are distinguished from others occurring on sugarcane leaves by their broken, wavy, irregular margins. Apparently chlorotic streak is not a completely systemic disease, nor do all the aerial parts of the plant appear to be affected. Abbott (4) claimed that complete recovery might occur even after the disease had developed.

The insidious nature of the disease makes diagnosis difficult for the untrained person, and, therefore, the damage caused by the virus is not so plainly seen. Although no systematic survey of the extent of the chlorotic streak has been undertaken in Puerto Rico, preliminary observations have indicated that the disease is widely prevalent in the northern, eastern, and

1 Assistant Agronomist and Phytopathologist, respectively, Agricultural Experiment Station, University of Puerto Rico, Río Piedras, P. R. The authors are indebted to Messers. A. Emmanuelli, C. Rivera López, and Dr. B. G. Capó for their cooperation in this project and to Mr. R. Rivera Bengoa, who designed the equipment for the treatment of the sugarcane cuttings.

2 Numbers in parentheses refer to Literature Cited, pp. 26-7. 
central cane regions of the Island. Possibly because P.O.J. 2878 is the variety most widely planted in Puerto Rico, the majority of the affected canes belong to this variety, although the disease has been found on other varieties as well.

Considering both the importance and extent of chlorotic streak, as well as the fact that the susceptible variety P.O.J. 2878 covers approximately

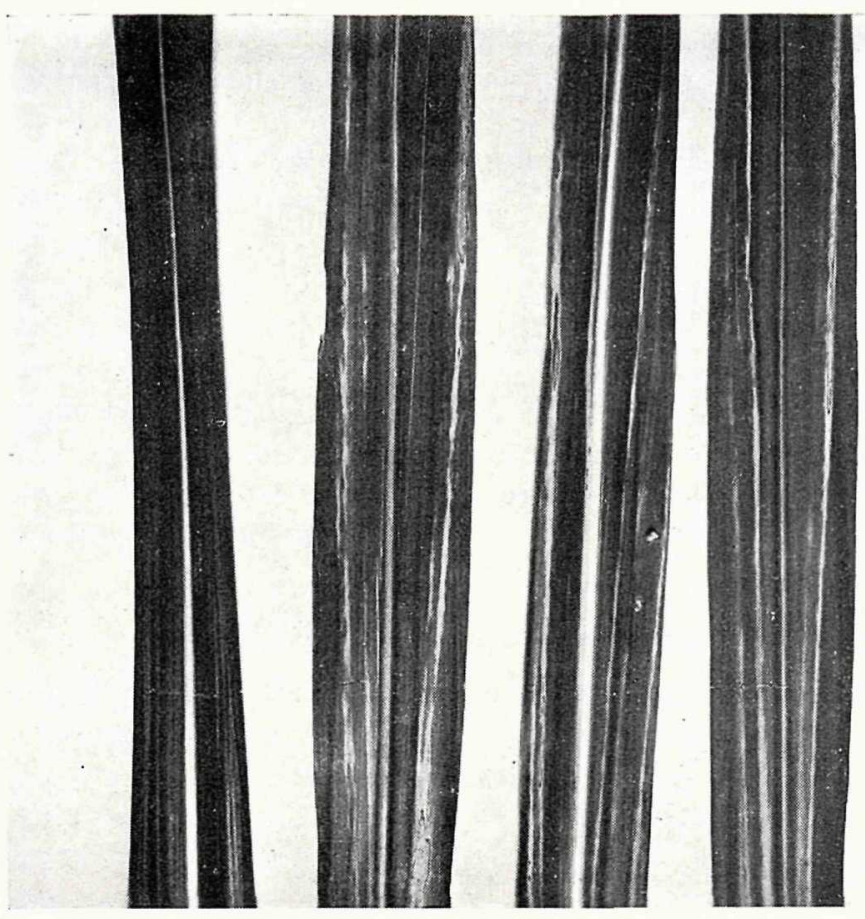

FIG. 1-Leaves of sugarcane showing chlorotic streak, as compared with a healthy leaf at the extreme left.

65 percent of the cane land planted in Puero Rico (8), a field experiment was performed to determine to what extent the plant cane and the successive ratoon crops were affected by this disease, especially as regarded yield and sugar content.

\section{EXPERIMENTAL PROCEDURE}

With this end in view, a field experiment was set up in May 1949, at Solís Farm, Río Piedras, on a Vega Alta clay loam. This area is located on the northern part of the Island and has a mean annual rainfall of about 72 inches. Results with the following were compared: (A) Infected seed, 
(B) noninfected seed, (C) infected-treated seed, and (D) noninfectedtreated seed.

Seed treatment consisted of immersing the seed in hot water $\left(52^{\circ} \mathrm{C}\right.$.) for 20 minutes and then submerging them in cold water until cool. Figure 2 presents the equipment used for heating the water and soaking the infected material.

The equipment for treating the seed, designed at the Agricultural Experiment Station, consisted of two empty 50-gallon drums, one of them

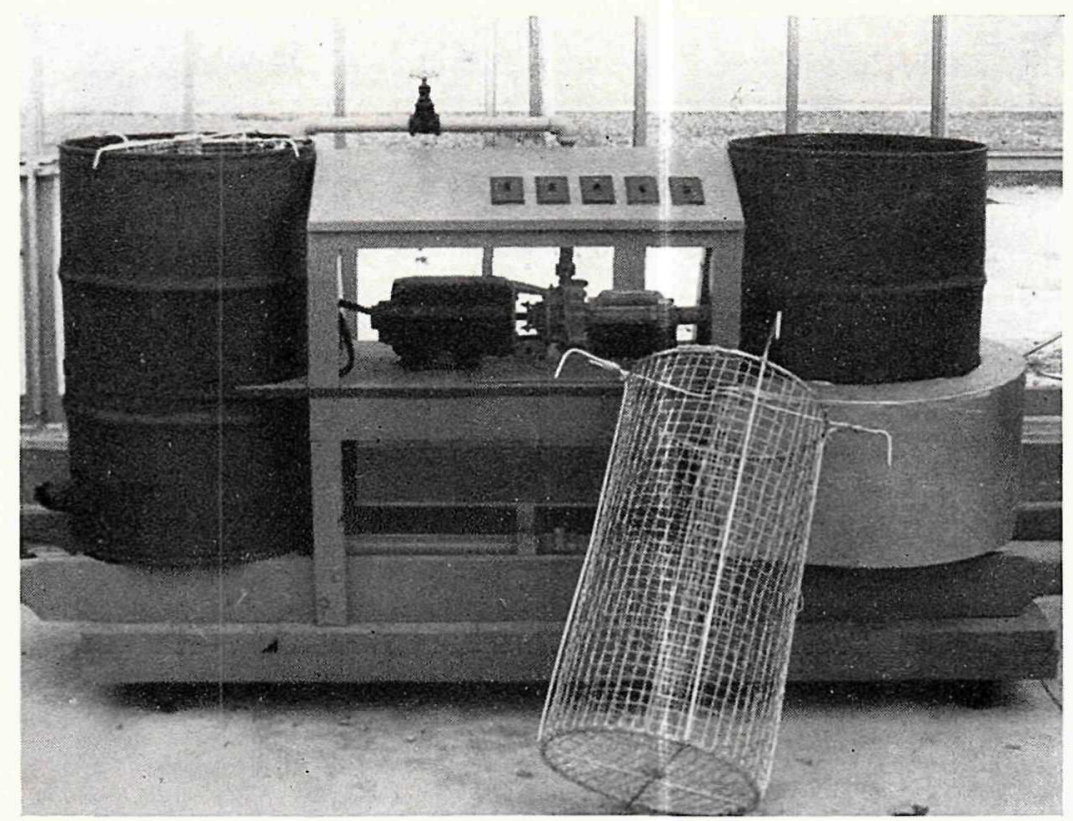

FIG. 2-Equipment used for heat-treating sugarcane seed pieces.

being heated by four 2,000-watt heating coils. The resistances were connected to a switchboard with 4 switches, one to each resistance. A pump was used to keep the water in continuous movement from one drum to the other. Cylindrical baskets were made of $1 / 2$-inch-mesh wire, 32 inches in height and 15 inches in diameter. In the center of each basket there was another mesh-wire cylinder, 1 inch in diameter and 32 inches in height for the thermometer. The basket was suspended in the drum by four $1 / 4^{-}$ inch solid wires bent at the ends at a $90^{\circ}$ angle. The basket was reinforced on the ends and bottom by a $1 / 4$-inch solid wire.

Before treating the seeds both drums were filled with water to a height about 6 inches from the top, and the four heating-coil switches were turned 
on. When the water reached a temperature of $56^{\circ}$ to $60^{\circ} \mathrm{C}$. a valve was opened and the hot water was circulated by means of the pump. When the circulating water reached $52^{\circ} \mathrm{C}$. in the two drums, two of the heating units were shut off. The baskets were filled with sugarcane seed pieces and submerged for 20 minutes. They were then placed in cold water to prevent further heat damage to the growing buds.

The field experiment was designed as a randomized block lay-out with 10 replications for each treatment. The plots were 18 feet wide by 24 feet long, or approximately one one-hundredth of an acre in area. The sugarcane planting material consisted of 3-eye seed pieces which were laid in the bottom of the furrow and covered with soil. Each plot had four furrows, $4 \frac{1}{2}$ feet apart. Twenty-four seed pieces were planted per furrow at a rate of approximately 10,000 per acre. The propagating material was carefully selected from diseased and sound canes in accordance with the schedule previously mentioned.

Planting, cultivation, and fertilizer applications were carried out in accordance with procedures usually followed by farmers throughout the Río Piedras area.

Percentage infestation counts were made yearly using all cane tops of the two middle rows from each plot. Each crop was harvested at 12 months of age.

\section{EXPERIMENTAL RESULTS}

The results with a plant cane and two ratoon crops are presented in tables 1 to 5. The infection caused a significant reduction in the yield of cane per acre. Noninfected, infected-treated, and noninfected-treated seed produced higher tonnages of cane than the infected-nontreated seed. These differences in cane tonnages were significant at the 1-percent level (table 1). Noninfected seed produced significantly higher yields at the 1percent level than infected seed in the plant cane and first ratoon crops. No significant differences were observed in the second ratoon crop. The results of the mean of the three crops followed the pattern of the plant and first ratoon crops.

Table 2 shows the mean yields of available $96^{\circ}$ sugar per acre. The results followed the same general trend as those for cane yields. Noninfected, infected-treated and noninfected-treated seed produced yields statistically higher at the 1-percent level than did infected seed, for the plant cane and first ratoon crops. The second ratoon crop failed to give significant results. In table 3 the percentage increases in sugar yields caused by treatments are shown. There were large (approximately 45 percent) increases in yields when noninfected seed were used. Increases of approximately 28 and 35 percent, respectively, were registered for the first two crops when the infected seed were treated with hot water. 
TABLE 1.-Mean yields of cane per acre for a plant cane and two ratoon crops, as affected by seed infection with chlorotic streak, treated and untreated

\begin{tabular}{|c|c|c|c|c|c|}
\hline \multirow{2}{*}{ Symbol } & \multirow{2}{*}{ Seed used } & \multicolumn{3}{|c|}{ Mean yields of cane per acre for- } & \multirow{2}{*}{$\begin{array}{l}\text { Mean of } \\
3 \text { crops }\end{array}$} \\
\hline & & $\begin{array}{c}\text { Plant cane } \\
1949-50\end{array}$ & $\begin{array}{l}\text { First ratoon } \\
\quad 1950-51\end{array}$ & $\begin{array}{c}\text { Second ratoon } \\
1951-52\end{array}$ & \\
\hline & & Tons & Tons & Tons & Tons \\
\hline A & Infected & 33 & 25 & 45 & 34 \\
\hline $\mathrm{B}$ & Noninfected & 46 & 33 & 48 & 42 \\
\hline $\mathrm{C}$ & Infected-treated & 41 & 34 & 48 & 41 \\
\hline $\mathrm{D}$ & Noninfected-treated & 40 & 33 & 49 & 41 \\
\hline
\end{tabular}

Minimum significant differences between the means of two treatments at:
5 -percent level
3.57
3.45
4.69
3.38
1-percent level
4.82
4.66
6.34
4.56

TABLE 2.-Mean yields of available $96^{\circ}$ sugar per acre for a plant cane and two ratoon crops, as affected by seed infection with chlorotic streak, treated and untreated

\begin{tabular}{|c|c|c|c|c|c|}
\hline \multirow{2}{*}{ Symbol } & \multirow{2}{*}{ Seed used } & \multicolumn{3}{|c|}{$\begin{array}{l}\text { Mean available } 96^{\circ} \text { sugar yields } \\
\text { per acre for- }\end{array}$} & \multirow{2}{*}{$\begin{array}{l}\text { Mean of } \\
3 \text { crops }\end{array}$} \\
\hline & & $\begin{array}{l}\text { Plant cane } \\
1949-50\end{array}$ & $\begin{array}{l}\text { First ratoon } \\
1950-51\end{array}$ & $\begin{array}{c}\text { Second ratoon } \\
1951-52\end{array}$ & \\
\hline & & $\begin{array}{l}\text { Hundred- } \\
\text { weights }\end{array}$ & $\begin{array}{l}\text { Hundred- } \\
\text { weights }\end{array}$ & $\begin{array}{l}\text { Hundred- } \\
\text { weights }\end{array}$ & $\begin{array}{l}\text { Hundred- } \\
\text { weights }\end{array}$ \\
\hline A & Infected & 76 & 68 & 109 & 84 \\
\hline $\mathrm{B}$ & Noninfected & 110 & 89 & 115 & 105 \\
\hline $\mathrm{C}$ & Infected-treated & 97 & 92 & 119 & 103 \\
\hline $\mathrm{D}$ & Noninfected-treated & 92 & 89 & 115 & 99 \\
\hline
\end{tabular}

Minimum significant difference between the means of two treatments at:
5-percent level
9.95
9.94
13.89
9.52
1-percent level
13.44
13.39
18.76
12.86

TABLE 3.-Percentage increase in yield of sugar per acre of a plant cane and two ratoon crops, as affected by seed infection with chlorotic streak, treated and untreated

\begin{tabular}{c|c|c|c}
\hline \multirow{2}{*}{ Treatments compared } & \multicolumn{3}{|c}{ Increase in yield ${ }^{1}$ for- } \\
& Plant cane & First ratoon & Second ratoon \\
& Percent & Percent & Percent \\
Noninfected vs. infected .......... & 44.74 & 30.88 & 5.50 \\
Infected-treated vs. infected..... & 27.63 & 35.29 & 9.17 \\
Noninfected-treated vs. infected... & 21.05 & 30.88 & 5.50 \\
Noninfected-treated vs. nonin- & & & 0 \\
fected........................ & -16.36 & 0 & 0 \\
Infected-treated vs. noninfected... & -11.82 & -3.37 & 3.47 \\
\hline
\end{tabular}

${ }^{1}$ Based on available $96^{\circ}$ sugar per acre. 
The mean available $96^{\circ}$ sugar percent cane for all crops was not affected by the infection (table 4 ). The first ratoon crops gave the highest available $96^{\circ}$ sugar percent cane, but it was about the same as for the other two crops, and no significant differences were observed between treatments.

Data on percentage infestation with chlorotic streak of a plant cane

TABLE 4.-Mean available $96^{\circ}$ sugar percent cane for a plant cane and two ratoon crops, as affected by seed infection with chlorotic streak, treated and untreated

\begin{tabular}{|c|c|c|c|c|c|}
\hline \multirow{2}{*}{ Symbol } & \multirow{2}{*}{ Seed used } & \multicolumn{3}{|c|}{ Mean available $96^{\circ}$ sugar per acre for- } & \multirow{2}{*}{$\begin{array}{l}\text { Mean of } \\
3 \text { crops }\end{array}$} \\
\hline & & $\begin{array}{l}\text { Plant cane } \\
1949-50\end{array}$ & $\begin{array}{c}\text { First ratoon } \\
1950-51\end{array}$ & $\begin{array}{c}\text { Second ratoon } \\
1951-52\end{array}$ & \\
\hline & & Percent & Percent & Percent & Percent \\
\hline $\mathrm{A}$ & Infected & 11.39 & 13.44 & 12.17 & 12.33 \\
\hline $\mathrm{B}$ & Noninfected & 11.89 & 13.51 & 12.01 & 12.47 \\
\hline $\mathrm{C}$ & Infected-treated & 12.00 & 13.55 & 12.26 & 12.61 \\
\hline $\mathrm{D}$ & Noninfected-treated & 11.46 & 13.48 & 11.66 & 12.19 \\
\hline
\end{tabular}

Minimum significant difference needed between the means of two treatments at:

5 -percent level

1 -percent level
0.60

.81
0.43

.59
0.73

.98
0.43 .58

TABLE 5.-Percentage infection with chlorotic streak of a plant cane and two ratoon crops, as affected by seed infection with chlorotic streak, treated and untreated

\begin{tabular}{|c|c|c|c|c|c|}
\hline \multirow{2}{*}{ Symbol } & \multirow{2}{*}{ Seed used } & \multicolumn{3}{|c|}{ Infection with chlorotic streak in- } & \multirow{2}{*}{$\begin{array}{l}\text { Mean o } \\
3 \text { crops }\end{array}$} \\
\hline & & $\begin{array}{l}\text { Plant cane } \\
1949-50\end{array}$ & $\begin{array}{c}\text { First ratoon } \\
\quad 1950-51\end{array}$ & $\begin{array}{c}\text { Second ratoon } \\
1951-52\end{array}$ & \\
\hline A & Infected & 51 & 41 & 10 & 34 \\
\hline $\mathrm{B}$ & Noninfected & 20 & 26 & 9 & 18 \\
\hline $\mathrm{C}$ & Infected-treated & 11 & 18 & 5 & 12 \\
\hline $\mathrm{D}$ & Noninfected-treated & 18 & 14 & 4 & 12 \\
\hline
\end{tabular}

Minimum significant difference needed between the means of two treatments at:
5 -percent level
10.08
9.54
4.78
4.79
1-percent level
13.61
12.89
6.45
6.47

and two ratoon crops are presented in table 5. The plants resulting from infected, nontreated seed pieces were severely attacked by chlorotic streak The incidence of the disease in a plant cane developed from noninfected seed was considerably lower.

The hot-water treatment was very effective in reducing the rate of infection. In the second ratoon crop the incidence of the disease was rather 
low for all treatments, probably because of unfavorable conditions for the development and manifestation of the disease symptoms.

\section{DISCUSSION}

Chlorotic streak, an infectious virus disease of sugarcane that spreads easily via cuttings, is largely confined to the humid section of the Island, being found much less frequently in the drier areas. Abbott, in Louisiana (1), has observed that excessive soil moisture accentuates the incidence of the disease.

Very little is known concerning the susceptibility of different varieties to the disease; however, field observations have shown that the sugarcane variety P.O.J 2878, which comprises about 65 percent of the sugarcane grown in Puerto Rico, is highly susceptible. Furthermore, some of the varieties originating in Barbados and Puerto Rico have shown marked susceptibility to the disease. The Barbados 34-104 and 37-161, the P.R. 902 and 905 , and the M. 336 are all particularly susceptible under certain climatic conditions.

Several investigators claim that the low or high incidence of the disease may be the result of nutritional disturbances (1-7). In some varieties applications of nitrogenous fertilizer to young plants have been observed to increase the number of leaf symptoms; however, heavy applications of nitrogen at frequent intervals during the life of the plant produced a high degree of recovery in some sugarcane varieties (1).

Chlorotic streak is sometimes difficult to detect symptomatically. The results for the first two crops indicate that a 20 - to 26-percent infection occurred in plants developed from noninfected seed. This infection may have occurred either because the presence of chlorotic streak virus was not detected in some of the apparently healthy plant matrial used, or because some of the noninfected material used became infected in the field. Several investigators $(5,6,9)$ have shown that the hot-water treatment used gives complete control of the disease in infected stock. The development of the disease in the cane produced from the treated seed pieces (treatments $\mathrm{C}$ and $\mathrm{D}$ ) after planting suggests that reinfection of the treated seed pieces occurs in the field.

In general, the results indicate that the damage caused by chlorotic streak disease can be effectively prevented by immersing the seed pieces in hot water (at $52^{\circ} \mathrm{C}$.) for a 20 -minute period prior to planting. As shown in tables 1 and 2, it is not advantageous to treat noninfected seed pieces; in fact, yield reductions were then observed in the plant crop.

\section{SUMMARY}

A field experiment was carried out at Río Piedras to determine the extent to which sugarcane yields are reduced by chlorotic streak. 
Results with the following were compared: (A) Infected seed, (B) noninfected seed, (C) infected-treated seed, (D) noninfected-treated seed. Cane developed from noninfected sugarcane seed pieces produced significantly higher yields than that developed from infected stock.

Immersion in hot water $\left(52^{\circ} \mathrm{C}\right.$. for 20 minutes) significantly reduced the incidence of the disease and increased the yields of cane and of sugar. An increase of about 45 percent in sugar production was obtained by planting noninfected healthy sugarcane seed pieces instead of infected nontreated seed pieces.

The proper selection of good seed pieces free from infection with chlorotic streak will give higher yields of cane without the expense of treating the seed pieces to control the infection.

\section{RESUMEN}

En la Estación Experimental Agrícola, en Río Piedras, se llevó a cabo un experimento con el objeto de determinar hasta qué punto la enfermedad, llamada raya clorótica, puede reducir los rendimientos de la cana de azúcar.

Se compararon los resultados de los siguientes tratamientos: (A) Semilla infectada, (B) semilla sana, (C) semilla infectada tratada, (D) semilla sana tratada. La caña desarrollada de pedazos de semilla sana, produjo rendimientos que fueron significativamente mayores que la desarrollada de pedazos de semilla infectada.

La inmersión de la semilla en agua caliente $\left(52^{\circ} \mathrm{C}\right.$. por 20 minutos), redujo significativamente la incidencia de la enfermedad y aumentó los rendimientos de la caña y del azúcar en la caña. Se logró un aumento, en un 45 por ciento, en los rendimientos de azúcar, cuando se sembró semilla sana, al compararse con la producción de los tratamientos con semilla infectada que no se trató.

Los resultados del experimento señalan el hecho de que si se selecciona adecuadamente la semilla para las siembras en el campo, de modo que esté libre de la raya clorótica, no sólo se consiguen mayores rendimientos de caña, si que también se evitan los gastos de tratar la semilla para controlar la infección.

\section{LITERATURE CITED}

1. Abbott, E. V., Influence of certain environmental conditions on chlorotic streak of sugarcane, Phytopath. 37 162-73 1947.

2. Adsuar, José, Chlorotic streak disease of sugarcane in Puerto Rico, Agric. Expt. Sta. Tech. Paper No. 3, 12 pp., August 1946.

3. Abbott, E. V. and J. W. Ingram, Transmission of chlorotic streak of sugarcane by the leaf hopper Draeculacephala portola, Phytopath. 32 99-1001942. 
4. Abbott, E. V. and Sass, E. John, Pathological Histology of sugarcane affected with chlorotic streak, J. Agri. Res., 70(6) 201-07 1945.

5. Beel, A. F., Queensland Agr. J., 404601933.

6. Martin, J. P., Hawaii Planter's Record, 343751930.

7. Martin, J. P., Rept. of the 56th. Ann. meeting of the Hawaiian Sugar Planters Assn., p. 30, 1937.

8. Silva E. and Serra, G., Census of sugarcane varieties grown in Puerto Rico for the 1949 crop, mimeographed E.A. 11, Department of Economics, Agric. Exp. Sta., Univ. P.R., Feb. 1950.

9. Wilbrink, G., Arch Suikerind Netherland Sch. Indii 3111923. 